\title{
Dynamics of prenatal screening: New developments challenging the ethical framework
}

Citation for published version (APA):

Dondorp, W., \& van Lith, J. (2015). Dynamics of prenatal screening: New developments challenging the ethical framework. Bioethics, 29(1), ii-iv. https://doi.org/10.1111/bioe.12127

Document status and date:

Published: 01/01/2015

DOI:

10.1111/bioe. 12127

Document Version:

Publisher's PDF, also known as Version of record

Document license:

Taverne

\section{Please check the document version of this publication:}

- A submitted manuscript is the version of the article upon submission and before peer-review. There can be important differences between the submitted version and the official published version of record.

People interested in the research are advised to contact the author for the final version of the publication, or visit the DOI to the publisher's website.

- The final author version and the galley proof are versions of the publication after peer review.

- The final published version features the final layout of the paper including the volume, issue and page numbers.

Link to publication

\footnotetext{
General rights rights.

- You may freely distribute the URL identifying the publication in the public portal. please follow below link for the End User Agreement:

www.umlib.nl/taverne-license

Take down policy

If you believe that this document breaches copyright please contact us at:

repository@maastrichtuniversity.nl

providing details and we will investigate your claim.
}

Copyright and moral rights for the publications made accessible in the public portal are retained by the authors and/or other copyright owners and it is a condition of accessing publications that users recognise and abide by the legal requirements associated with these

- Users may download and print one copy of any publication from the public portal for the purpose of private study or research.

- You may not further distribute the material or use it for any profit-making activity or commercial gain

If the publication is distributed under the terms of Article $25 \mathrm{fa}$ of the Dutch Copyright Act, indicated by the "Taverne" license above, 


\section{EDITORIAL}

\section{DYNAMICS OF PRENATAL SCREENING: NEW DEVELOPMENTS CHALLENGING THE ETHICAL FRAMEWORK}

In many countries, (eg. in the UK, France, Denmark, the Netherlands) prenatal screening for fetal abnormalities such as Down's syndrome is offered as a publicly or collectively funded public health programme. But unlike other such programmes (e.g. breast cancer screening) prenatal screening is not understood as aimed at prevention, in the sense of reducing the burden of disease in society. ${ }^{1}$ Relevant policy documents stress that as a public health service, prenatal screening is special in being aimed, not at prevention, but at enabling autonomous reproductive choice. ${ }^{2}$ It is felt that the practice can only thus escape the moral criticisms that have always accompanied its existence. If the aim is not to reduce the number of children being born with Down's syndrome and other abnormalities, but to enable pregnant women or couples to make their own reproductive choices, this would avoid the charge that prenatal screening trivializes abortion decisions by promoting them as a public health instrument. This would also answer what is known as the 'disability rights critique,, ${ }^{3}$ which holds that prenatal screening sends a discriminatory message about the worth of the lives of people living with the relevant conditions.

Although not all commentators do think that the retreat to 'enabling autonomous decision making' really removes the sting, ${ }^{4}$ especially with regard to the latter challenge, it seems that this account of what the aim of prenatal screening should and should not be is widely endorsed among policymakers and authorities in the field. Enabling autonomous choice is reflected in the relevant guidelines

\footnotetext{
${ }^{1}$ N. Juth \& C. Munthe. The Ethics of Screening in Health Care and Medicine: Serving Society or Serving the Patient? Dordrecht, Heidelberg, London, New York: Springer Science+Business Media; 2012; Health Council of the Netherlands. Screening: between hope and hype. The Hague: Health Council of the Netherlands; 2008. Available at: www.gr.nl [accessed 2014 August 21].

${ }^{2}$ Sundhedsstyrelsen. Retningslinjer for fosterdiagnostik. Prcenatal Information, Risikovurdering, Rådgivning og Diagnostik. København: Sundhedsstyrelsen; 2004. Available at: www.sst.dk [accessed 2014 August 21]; Health Council of the Netherlands. Prenatal Screening: Down's Syndrome, Neural tube defects, Routine-ultrasonography. The Hague: Health Council of the Netherlands; 2001. Available at: www.gr.nl [accessed 2014 August 21]; UK National Screening Committee. Criteria for Appraising the Viability, Effectiveness and Appropriateness of a Screening Programme. Available at: http://www.screening .nhs.uk/criteria [accessed 2014 August 21].

${ }^{3}$ E. Parens \& A. Asch. Disability Rights Critique of Prenatal Genetic Testing: Reflections and Recommendations. Ment Retard Dev Disabil Res Rev 2003; 9: 40-47.

${ }^{4}$ J.S. Reinders. The Future of the Disabled in Liberal Society. An Ethical Analysis. Notre Dame: ND University press; 2000.
}

and position statements stressing the importance of providing balanced information and the ideal of non-directive counselling. Caregivers should present the screening as an option while avoiding any suggestion that pregnant women should take the test. Historically, the ethos of reproductive autonomy and professional non-directivity is rooted in the tradition of individual genetic counseling that itself arose in reaction to the eugenic ideas and practices of the earlier 20 th century. ${ }^{5}$

Clearly, the connection of this ethos with a routinely offered screening programme is a substantial challenge. If enabling autonomous decision-making is the very aim of the programme, then this should be reflected in every aspect of how the screening is presented, offered, carried out and evaluated. ${ }^{6}$ In the literature, there have been too many reports revealing that this is often not the case, and much of the ethical debate of the past decades has turned on these discrepancies between the confessed aim of prenatal screening and the reality of clinical practice. ${ }^{7}$

Over the past decades, the concept of prenatal screening itself has only changed slightly. The focus was mainly on Down's syndrome, with karyotyping as the diagnostic test giving clear results in most cases. One further form of prenatal screening is the routine second trimester fetal anomaly scan, where the wide range of possible findings with their different implications for the health prospects of the future child challenges the feasibility of providing adequate pretest information and enabling autonomous choice. ${ }^{8}$ But this scan is also done for other reasons, including pregnancy monitoring and maternal-fetal bonding, which may have contributed to this problem being largely ignored, or regarded more as an exception confirming the rule than as revealing the limits of the autonomy paradigm.

With the dynamics of recent technological developments the field is now rapidly changing. As explained in the introductory article to this issue, by De Jong and colleagues, the thrust of those developments is towards noninvasive testing, earlier in pregnancy, and for a (much)

\footnotetext{
${ }^{5}$ C.G. van El, T. Pieters \& M. Cornel. Genetic Screening and Democracy: Lessons from Debating Genetic Screening Criteria in the Netherlands. J Community Genet 2012; 3: 79-89.

${ }^{6}$ A.J. Clarke. Prenatal screening. Paradigms and Perspectives. In: D.S. Harper, A.J. Clarke, editors. Genetics, Society and Clinical Practice. Oxford: Bios Scientific Publishers; 1997. pp. 119-140.

${ }^{7}$ M. van den Berg, D.R. Timmermans, L.P. ten Kate, et al. Informed Decision Making in the Context of Prenatal Screening. Patient Educ Couns. 2006; 63: 110-117; V. Seavilleklein. Challenging the Rhetoric of Choice in Prenatal Screening. Bioethics 2009; 23: 68-77.

${ }^{8}$ R. Cash, M. Manogaran, H. Sroka, et al. An Assessment of Women's Knowledge of and Views on the Reporting of Ultrasound Soft Markers During the Routine Anatomy Ultrasound Examination. J Obstet Gynaecol Can 2010; 32: 120-125.
} 
wider range of conditions. ${ }^{9}$ At the moment, the expansion of the scope of what is tested for is mainly seen at the stage of invasive follow-up testing, with karyotyping being replaced by genomic technologies capable of also finding submicroscopic chromosome abnormalities and other genetic variation, including variants of (still) unknown clinical significance. ${ }^{10}$ At the same time, the breakthrough of non-invasive prenatal testing (NIPT) promises safer testing for Down's syndrome and other common aneuploidies (trisomy 13 and 18), as its greater accuracy enables a massive reduction of the need for invasive follow-up, thus also avoiding most of the procedure-related miscarriage risk. ${ }^{11}$ The confluence of these developments may in the not too distant future lead to the scenario of early, safe and broad scope prenatal testing. As there is proof of principle that the whole fetal genome can be sequenced from cell free fetal DNA found in maternal plasma, it is probably only a matter of time before it is ready and sufficiently affordable for routine clinical application. ${ }^{12}$

The question arises as to what these developments entail for the received ethical framework, with its emphasis on enabling autonomous choice. On the one hand, it would seem that the availability of more options for choice is very much in line with that ideal. On the other hand, the problems already referred to with regard to ultrasound screening are bound to multiply: how to provide balanced information and how to help women or couples to make informed decisions? What does this tell us about the autonomy paradigm? Is it fit to guide the practice of prenatal screening into the new era of next generation sequencing? If it is in need of adaptation, then how to avoid the moral pitfalls that led to phrasing the aim of prenatal screening in those terms?

This issue of Bioethics contains a collection of articles addressing this question from different angles. The article by Hewison shows how the personal trade-offs that pregnant women face in the context of prenatal screening are becoming increasingly complex; it ends with the sober warning that "nobody yet knows how a national screening programme can deliver meaningful individualized choice in the era of multiple testing'. ${ }^{13}$ Deans and

\footnotetext{
${ }^{9}$ A. De Jong, I. Maya \& J. Van Lith. Prenatal Screening: Current Practice, New Developments, Ethical Challenges. Bioethics 2015; 29 : $1-8$.

${ }^{10}$ A. Vetro, K. Bouman, R. Hastings, et al. The Introduction of Arrays in Prenatal Diagnosis: a Special Challenge. Hum Mutat 2012; 33: $923-$ 929

${ }^{11}$ D.W. Bianchi \& L. Wilkins-Haug. Integration of Noninvasive DNA Testing for Aneuploidy into Prenatal Care: What Has Happened Since the Rubber Met the Road? Clin Chem 2014; 60: 78-87.

12 Y.M. Lo. Non-invasive Prenatal Testing Using Massively Parallel Sequencing of Maternal Plasma DNA: From Molecular Karyotyping to Fetal Whole-genome Sequencing. Reprod Biomed Online 2013; 27 : 593-598.

13 J. Hewison. Psychological Aspects of Individualized Choice and Reproductive Autonomy in Prenatal Screening. Bioethics 2015; 29: 9-18.
}

colleagues explore an issue that is also briefly raised by Hewison, namely that with the miscarriage risk falling away, some women or couples may want to have NIPTbased screening 'just for information', meaning: with no intention to ask for an abortion if the fetus were found to have the condition (or any of the conditions) tested for. ${ }^{14}$

Already, with NIPT as a much more accurate first-line screening test for common aneuploidies than the current approach, it is entirely conceivable that some couples whose choice would be 'preparation' rather than abortion, may find a positive NIPT-result sufficiently informative and would not risk a miscarriage for greater certainty. This may lead to a greater uptake of prenatal screening, also by couples who would not consider an abortion. In terms of the autonomy paradigm this can be considered a moral gain as it would mean that more women can be helped to make what for them would be a meaningful reproductive decision. But, as Deans and colleagues explain, the prospect of safe and genome wide prenatal testing opens up the further possibility of people wanting such a test 'just for curiosity', including wanting information about health risks beyond serious childhood conditions or about non-health related traits. As their analysis shows, concerns about the interests or privacy of the future person stand in the way of simply embracing this as a further instance of the reproductive autonomy that prenatal screening is supposed to serve.

In his contribution, Wilkinson observes that 'pure reproductive autonomy', in the sense of enabling prospective parents to make whatever reproductive choices they find important, could never be the aim of a screening programme offered as a public health service. ${ }^{15}$ And indeed, this was not envisaged at the time of those earlier prevention-versus-autonomy debates. At the time, 'enabling autonomous choice' had the much more limited meaning of allowing pregnant women and their partners to decide for themselves whether or not they wanted a test for Down's syndrome (and perhaps a very small number of other conditions), and to make further autonomous decisions with regard to possible choices emerging as a consequence of having that specific test. As the scope of the test offer was fixed and as this determined the range of possible choices, this was not 'pure' but qualified autonomy. But criteria were never spelled out, and the qualification remained implicit.

Now that the technological dynamics of the field inevitably leads to the question what the scope of prenatal screening should be, it also reveals that the autonomy paradigm leaves us empty-handed when it comes to answering that question. According to Wilkinson, the

\footnotetext{
${ }^{14}$ Z. Deans, A. Clarke \& A. Newson. For your Interest? The Ethical Acceptability of Using Non-invasive Prenatal Testing to Test 'Purely for Information'. Bioethics 2015; 29: 19-25.

${ }^{15}$ S. Wilkinson. Prenatal Screening, Reproductive Choice, and Public Health. Bioethics 2015; 29: 26-35.
} 
obvious way out here is to acknowledge that as a public health service, prenatal screening should serve public health goals. In what he terms 'public health pluralism', prenatal screening would have the reduction of the prevalence of disorders and disease among the new-born population as a central aim, while 'respecting' but not enhancing or maximizing reproductive autonomy. This, he says, would have the further advantage of not burdening the practice with impossible requirements regarding informed decision-making. While this may sound attractive, it raises the obvious question if this would not again make the practice vulnerable to the 'disability rights critique'. Wilkinson does not deny this vulnerability, but challenges the claim that the autonomy paradigm fares any better in this respect.

In a further contribution to this issue, Munthe draws a different conclusion. ${ }^{16} \mathrm{He}$ agrees that in publicly funded prenatal screening programmes, it will be necessary to limit the scope of what is tested for in a way that may lead to stigmatizing people living with the relevant conditions. But instead of accepting this as to some extent unavoidable, his 'radical proposal' is to move most of prenatal testing to the commercial market where the autonomy paradigm can be upheld and no stigmatizing limits would have to be imposed upon the range of testing options that people may want to make use of. Most, but not all: the proposal allows for keeping a drastically downscaled prenatal screening service in the public health realm, but only for conditions so severe that anyone would agree that providing this service is needed to help prospective parents avoid significant suffering. Down's syndrome would probably not be on that list. According to Munthe, promoting inclusion and support for people living with disabilities and disorders would reduce the perceived need for prenatal screening and would be the morally superior approach for society to take.

The final contribution is by De Jong and De Wert, the organizers of the symposium where most of these articles were first presented. ${ }^{17}$ They argue for a qualified version of the autonomy paradigm that would allow maintaining prenatal screening as a public health service, with important benefits in terms of equal access and standardized quality control, while limiting its scope to (serious) childhood conditions. ${ }^{18}$ Reasons for thus limiting the screening offer would include keeping the service affordable for society, avoiding information overload that would undermine rather than serve autonomous decision-making,

\footnotetext{
${ }^{16}$ C. Munthe. A New Ethical Landscape of Prenatal Testing: Individualizing Choice to Serve Autonomy and Promote Public Health: a Radical Proposal. Bioethics 2015; 29: 36-45.

${ }^{17}$ Symposium 'Individualized choice: a new approach to reproductive autonomy in prenatal screening?', held at the Brocher Foundation, Geneva Switzerland, 6-7 April 2013.

18 A. de Jong \& G. de Wert. Prenatal Screening: an Ethical Agenda for the Near Future. Bioethics 2015; 29: 46-55.
}

and respecting the autonomy rights of the future child. ${ }^{19}$ While emphasizing the undiminished ethical importance of the 'autonomy versus prevention' distinction, they point at further developments that may lead to a blurring of this distinction in practice. As is already the case with ultrasound screening, new tests can and will increasingly be used for a dual purpose: not just to find fetal abnormalities that the prospective parents may regard as a reason to ask for an abortion, but also to test for conditions, such as pregnancy monitoring markers, that are relevant for a healthy outcome of the pregnancy for mother and child. ${ }^{20}$ Moreover, with further technological advancement, it may become more often the case that prenatal detection of fetal abnormalities opens up possibilities for fetal treatment rather than only a choice between having an abortion and preparing for the birth of a child with a serious disorder. ${ }^{21}$ As De Jong and De Wert make clear in their 'agenda for further research and debate', the present ethical framework is far from ready to deal with the implications of these developments, also in terms of defining professional and parental responsibilities.

Notwithstanding their different perspectives and positions, all contributors to this Special Issue agree on the importance and urgency of bringing the ethical framework for prenatal screening in report with the rapid technological developments. As the choices facing the field are not just technical but also ethical, and as they affect society as a whole, bioethics can and should make a difference here. The alternative is indeed to leave it to the technological imperative to determine what prenatal screening will look like in the near future.

\section{WYBO DONDORP AND JAN VAN LITH}

Wybo Dondorp (PhD) is a senior researcher in Biomedical Ethics at the Department of Health, Ethics \& Society, Maastricht University, The Netherlands, research schools CAPHRI and GROW. His research interests include the ethics of screening and medically assisted reproduction. He is a member of the Standing Committee on Population Screening of the Health Council of the Netherlands and coordinates the Special Interest Group on Ethics of the International Society for Prenatal Diagnosis and Therapy (ISPD).

Jan van Lith (MD, PhD) is Professor and Chairman of Obstetrics and Fetal Medicine at the Leiden University Medical Centre (LUMC) and president of the International Society for Prenatal Diagnosis and Therapy (ISPD). He has been actively involved in the development and organization of prenatal diagnosis and screening in the Netherlands since the early 1990s. His PhD was on first trimester Down's syndrome screening (1993)

19 A. de Jong, W.J. Dondorp, S.G. Frints, et al. Advances in Prenatal Screening: the Ethical Dimension. Nat Rev Genet 2011; 12: 657-663.

${ }^{20}$ J.M. Jørgensen, P.L. Hedley, M. Gjerris, et al. Including Ethical Considerations in Models for First-trimester Screening for Preeclampsia. Reprod Biomed Online 2014; 28: 638-643.

${ }^{21}$ D.W. Bianchi. From Prenatal Genomic Diagnosis to Fetal Personalized Medicine: Progress and Challenges. Nat Med 2012; 18: 10411051. 